\title{
RICE GROWN IN NUTRIENT SOLUTION WITH DOSES OF MANGANESE AND SILICON ${ }^{(1)}$
}

\author{
Luiz Antônio Zanão Júnior ${ }^{(2)}$, Renildes Lúcio Ferreira Fontes ${ }^{(3)}$, Júlio César \\ Lima Neves ${ }^{(3)}$, Gaspar Henrique Korndörfer ${ }^{(4)}$ \& Vinícius Tavares de Ávila ${ }^{(5)}$
}

\begin{abstract}
SUMMARY
Although silicon is not recognized as a nutrient, it may benefit rice plants and may alleviate the Mn toxicity in some plant species. The dry matter yield (root, leaf, sheaths and leaf blade) and plant architecture (angle of leaf insertion and leaf arc) were evaluated in rice plants grown in nutrient solutions with three Mn doses, with and without $\mathrm{Si}$ addition. The treatments were arranged in a $2 \times 3$ factorial [with and without $\left(2 \mathrm{mmol} \mathrm{L}^{-1}\right) \mathrm{Si}$; three $\mathrm{Mn}$ doses $\left(0.5 ; 2.5\right.$ and $\left.10 \mu \mathrm{mol} \mathrm{L} \mathrm{L}^{-1}\right)$ ], in a randomized block design with 4 replications. The experimental unit was a $4 \mathrm{~L}$ plastic vase with 4 rice (Metica-1 cultivar) plants. Thirty nine days after keeping the seedlings in the nutrient solution the plant dry matter yield was determined; the angle of leaf insertion in the sheath and the leaf arc were measured; and the $\mathrm{Si}$ and Mn concentrations in roots, sheaths and leaves were determined. The analysis of variance ( $\mathrm{F}$ test at 5 and $1 \%$ levels) and the regression analysis (for testing plant response to $\mathrm{Mn}$ with the Si treatments) were performed. The Si added to the nutrient solution increased the dry matter yield of roots, sheaths and leaf blades and also decreased the angle of leaf blade insertion into the sheath and the foliar arc in the rice plant. Additionally, it ameliorated the rice plant architecture which allowed an increase in the dry matter yield. Similarly, the addition of Mn to the solution improved the architecture of the rice plants with gain in dry matter yield. As Si was added to the nutrient solution, the concentration of Mn in leaves decreased and in roots increased thus alleviating the toxic effects of Mn on the plants.
\end{abstract}

Index terms: Oryza sativa, mineral plant nutrition, beneficial element.

\footnotetext{
(1) Paper extracted from the Master's dissertation of first author submitted to the Soil and Plant Nutrition Graduation Program, Federal University of Viçosa. Received for publication in July 2009 and and approved in July 2010.

(2) Researcher, Agronomic Institute of Paraná - IAPAR. CEP 84001-970 Ponta Grossa (PR). E-mail: lzanao@iapar.br

${ }^{(3)}$ Department of Soil Science and Plant Nutrition, Federal University of Viçosa - UFV. CEP 36570-000 Viçosa (MG). E-mails: renildes@ufv.br; julio_n2003@yahoo com.br

(4) Institute of Agronomy, Federal University of Uberlândia, CEP 38400-902 Uberlândia (MG). E-mail: ghk53@uol.com.br

(5) Undergratuated in Agronomy, Federal University of Viçosa. E-mail: vtasolosufv@yahoo.com.br
} 


\title{
RESUMO: ARROZ CULTIVADO EM SOLUÇÃO NUTRITIVA COM DOSES DE MANGANÊS E SILÍCIO
}

\begin{abstract}
O silício destaca-se por exercer vários benefícios para a cultura do arroz, apesar de não ser considerado um nutriente. Um desses benefícios é que ele pode amenizar a toxidez causada por Mn em algumas espécies de plantas. Objetivou-se com este trabalho avaliar a produção de matéria seca (raizes, bainhas e limbo foliar) e a arquitetura da parte aérea (ângulo de inserção e arco foliar) de plantas de arroz cultivadas em soluções nutritivas com três doses de Mn, na presença e ausência de $\mathrm{Si}$. Os tratamentos foram dispostos em esquema fatorial $2 \times 3$ [ausência e presença $\left(2 \mathrm{mmol} \mathrm{L}^{-1}\right)$ de Si; e três doses de $\mathrm{Mn}\left(0,5,2,5\right.$ e $\left.\left.10 \mu \mathrm{mol} \mathrm{L} \mathrm{L}^{-1}\right)\right]$, em blocos casualizados com quatro repetições, sendo a unidade experimental $4 \mathrm{~L}$ de solução nutritiva em vaso plástico com quatro plantas de arroz. Trinta e nove dias após a colocação das plântulas na solução com os tratamentos, foi determinada a produção de matéria seca; mediu-se o ângulo de inserção da folha na bainha e o arco foliar; e determinaram-se os teores de Si e Mn nas raizes, bainhas e folhas. Foi feita a análise de variância dos dados (teste $F$ a $5 \%$ ) e o ajuste de equações de regressão para as respostas das plantas às doses de Mn dentro de cada nível de Si. O Si proporcionou aumento na produção de matéria seca de raizes, bainhas e folhas. Sua adição à solução resultou em diminuição do ângulo de inserção da folha na bainha e também do arco foliar, o que resultou em melhoria na arquitetura da planta, com favorecimento da produção de matéria seca. O acréscimo de Mn à solução, também, melhorou a arquitetura da planta de arroz, resultando em ganho na produção de matéria seca. Houve diminuição nos teores foliares de Mn e aumento em seus teores radiculares com a adição de Si à solução, o que contribuiu para diminuir os efeitos negativos do excesso de Mn nas plantas.
\end{abstract}

Termos de indexação: Oryza sativa, nutrição mineral de plantas, elemento benéfico.

\section{INTRODUCTION}

According to the Instituto Rio Grandense do Arroz (2004), the genetic potential for the production of current irrigated rice cultivars in Brazil is between 10 and $12 \mathrm{tha}^{-1}$, a figure well above the average yield achieved in the 2005/2006 season, $3.875 \mathrm{t} \mathrm{ha}^{-1}$. The development of cultivation techniques and the development of genotypes adapted to different environments make possible an annual increase in productivity of this crop in the country.

Rice can be grown in two systems, on highlands (dryland rice) and lowlands (irrigated rice). In the dryland system a lower level of technology is used, there is less yield stability and lower productivity compared to the irrigated system. The irrigated system occupies $55 \%$ of cultivated area in the world and represents $75 \%$ of total production (Fairhurst \& Dobermann, 2002; Fageria et al., 2008). In the irrigated system several nutritional disorders may occur e.g. toxicity caused by $\mathrm{Mn}$. In this situation, low concentrations of $\mathrm{O}_{2}$ in the soil facilitates the reduction of this nutrient (Ponnamperuma, 1972) to soluble $\mathrm{Mn}^{2+}$, which can reach concentrations toxic to plants (Sposito, 1982). The high concentration of $\mathrm{Mn}^{2+}$ in the rhizosphere may also result in antagonism between this micronutrient and other nutrients like $\mathrm{Fe}, \mathrm{Ca}, \mathrm{Mg}$ and $\mathrm{Zn}$ (Kabata-Pendias \& Pendias, 1985; Fageria et al., 2008).

Mn takes part in the photochemical stage of photosynthesis, the multiplication and functioning of chloroplasts, the synthesis of chlorophyll and is an activator or a cofactor of more than 35 enzymes (Malavolta et al., 1997). The toxicity caused by Mn most severely affects the shoots rather than the roots of the plants, due to its accumulation in the leaves, causing characteristic symptoms. The most common are, small dark necrotic spots bordered by chlorotic tissue in older leaves, and shriveling in new leaves internerval chlorosis and along the leaf margins (ElJaoual \& Cox, 1998).

In general, plant species differ greatly in foliar $\mathrm{Mn}$ concentration. Appropriate concentrations (30$\left.500 \mathrm{mg} \mathrm{kg}^{-1}\right)$, deficiency (10-20 mg kg-1) and toxicity (200-5300 mg kg-1) (Edwards \& Asher, 1982; Clarkson, 1988) depend on the species, genotype, environmental conditions (temperature, humidity, $\mathrm{pH}$, light, source of nitrogen), nutritional interactions with $\mathrm{Ca}, \mathrm{Mg}, \mathrm{Fe}, \mathrm{P}, \mathrm{Mo}$ and $\mathrm{Si}$ and the action of mycorrhizae (El-Jaoual \& Cox, 1998). Previous studies show that in rice cultivars tolerant to high concentrations of $\mathrm{Mn}$, its accumulation occurs in the leaves. And depending on the species, the excess of $\mathrm{Mn}$ is stored in vacuoles, the cell wall or in the thylakoids (Lidon \& Teixeira, 2000).

Silicon is considered abenefitial element to rice which is one of the species that accumulate more $\mathrm{Si}$ in their tissues (Ma et al., 2001, Liang et al., 2007). An estimated production of $5 \mathrm{t} \mathrm{ha}^{-1}$ of grain removes $230-470 \mathrm{~kg}$ of Si from soil (Savant et al., 1997). In the biogeochemical cycle of $\mathrm{Si}$, the major drain is represented by the plant, forming amorphous silica 
in the leaves (Basile-Doelsch et al., 2005). The decline in rice productivity in some regions of the world may reflect this finding. Worldwide, the annual extraction of $\mathrm{Si}$ by plants is estimated at 210-224 Mt (Matichenkov et al., 2001).

Among the benefits that Si brings to rice, it can be stressed the increase in plant growth production and the resistance to stress conditions such as diseases, pests, drought, salinity and lodging. Moreover, there is a reduction in the sterility of flowers and an increase in the photosynthetic rate due to the maintenance of more erect and rigid leaves, with greater light interception. Many of these benefits are attributed to the silica layer that accumulates in the leaves, below the cuticle (Ma, 2004; Liang et al., 2007). Alvarez \& Datnoff (2001) analyzed the economic potential of the application of $\mathrm{Si}$ in the integrated management and sustainable rice production in several producer countries of this cereal in the world. They concluded that the gains obtained from the implementation of this element exceed the costs of application.

Si can also alleviate the toxicity caused by $\mathrm{Mn}, \mathrm{Fe}$ and $\mathrm{Al}$, a fact verified in several species such as rice, cowpea and cucumber (Liang et al., 2007). Some explanations for this effect, such as the reduction of the transport of $\mathrm{Mn}$ from roots to shoots and the homogeneity of its distribution, avoiding the concentration of spots on the leaves and the formation of necrotic spots, have been suggested (Horst \& Marschner, 1978). In more recent studies, Rogalla \& Römheld (2002) reported evidences of the mechanisms involved in reducing this toxicity.

Among other benefits, the use of $\mathrm{Si}$ in rice nutrition could be an alternative to alleviate problems related to toxicity caused by $\mathrm{Mn}$ in environments prone to this occurrence. This study aimed to evaluate the plant growth, the plant architecture, and the contents of $\mathrm{Mn}$ and $\mathrm{Si}$ in parts of rice plants grown in nutrient solutions containing doses of these two elements.

\section{MATERIAL AND METHODS}

Plants were grown in hydroponics, in a greenhouse from the Soil Science Department at the Federal University of Viçosa, with the treatments arranged in a $2 \times 3$ (0 or $2 \mathrm{mmol} \mathrm{L}^{-1} \mathrm{Si} ; 0.5 ; 2.5$ and $10 \mathrm{mmol} \mathrm{L}^{-1}$ $\mathrm{Mn}$ ) factorial with four replications in a randomized block design. The experimental unit consisted of $4 \mathrm{~L}$ of a solution in a plastic pot with four rice plants (cultivar Metica-1) obtained from germinated seeds (six days in germinator at $25{ }^{\circ} \mathrm{C}$ ) on paper germitest moisted with distilled water. After removing from the germinator, the seedlings were grown for three days on a nutrient solution diluted to half strength. This solution was formulated with $1.25 \mathrm{mmol} \mathrm{L}^{-1} \mathrm{~K}$ $\left(\mathrm{KNO}_{3}\right) ; 0.25 \mathrm{mmol} \mathrm{L}^{-1} \mathrm{P}\left(\mathrm{NH}_{4} \mathrm{H}_{2} \mathrm{PO}_{4}\right) ; 3.75 \mathrm{mmol} \mathrm{L}^{-1}$ $\mathrm{N}\left[\mathrm{KNO}_{3}, \mathrm{NH}_{4} \mathrm{Cl}, \mathrm{Ca}\left(\mathrm{NO}_{3}\right)_{2} \cdot 4 \mathrm{H}_{2} \mathrm{O}\right.$ and $\left.\mathrm{NH}_{4} \mathrm{H}_{2} \mathrm{PO}_{4}\right)$;
$1.0 \mathrm{mmol} \mathrm{L}^{-1} \mathrm{Ca}\left[\mathrm{Ca}\left(\mathrm{NO}_{3}\right)_{2}.\right] ; 0.5 \mathrm{mmol} \mathrm{L}^{-1} \mathrm{Mg}$ $\left(\mathrm{MgSO}_{4}\right) ; 0.5 \mathrm{mmol} \mathrm{L}^{-1} \mathrm{~S}\left(\mathrm{MgSO}_{4}\right) ; 20 \mathrm{mmol} \mathrm{L}^{-1} \mathrm{Fe}$ (Fe-EDTA); $0.3 \mathrm{mmol} \mathrm{L}^{-1} \mathrm{Cu}\left(\mathrm{CuSO}_{4} .5 \mathrm{H}_{2} \mathrm{O}\right)$; $0.33 \mathrm{~mol} \mathrm{~L}^{-1} \mathrm{Zn}\left(\mathrm{ZnSO}_{4} \cdot 7 \mathrm{H}_{2} \mathrm{O}\right) ; 11.5 \mathrm{mmol} \mathrm{L}^{-1} \mathrm{~B}$ $\left(\mathrm{H}_{3} \mathrm{BO}_{3}\right)$ and $0.1 \mathrm{mmol} \mathrm{L}^{-1} \mathrm{Mo}\left(\mathrm{Na}_{2} \mathrm{MoO}_{4} \cdot 2 \mathrm{H}_{2} \mathrm{O}\right)$, according to Zanão Junior et al. (2009a). After this period, the seedlings were sorted according to their uniformity and placed in pots containing a nutrient solution with the addition of $\mathrm{Si}\left(\mathrm{H}_{4} \mathrm{SiO}_{4}\right)$ and $\mathrm{Mn}$ $\left(\mathrm{MnCl}_{2} \cdot 4 \mathrm{H}_{2} \mathrm{O}\right)$ to establish the treatments. The $\mathrm{H}_{4} \mathrm{SiO}_{4}$ was obtained by passing a solution of potassium silicate through a column of cation exchange resin (Ma et al., 2001).

The solutions in each vessel were changed every four days, daily, and the volumes restored with distilled water. This procedure was done along with monitoring and adjusting $\mathrm{pH}$ which was maintained near $5.6 \pm 0.2$ by adding $\mathrm{NaOH}$ or $\mathrm{HCl} 1 \mathrm{~mol} \mathrm{~L}^{-1}$. The plants were held in the vessels using lids made of expanded polystyrene coated with aluminum foil.

After a growth period of 39 days, on each plant, the angle of insertion of leafs number 6,7 and 8 (Yoshida, 1981) was measured with the aid of a compass and a protractor, and the average angle was calculated. On the same leaves and at the same time the leaf arc was measured, as illustrated in figure 1, to characterize the degree of curvature or bend of the leaf blade. After these measurements, the plants were cut and separated into roots and leaves (leaf blades and sheaths). These parts were washed with distilled water, dried in an oven with air circulation at $65{ }^{\circ} \mathrm{C}$ for $72 \mathrm{~h}$ and weighed to determine dry matter production of roots and shoots (sum of dry matter of leaf blades and sheaths).

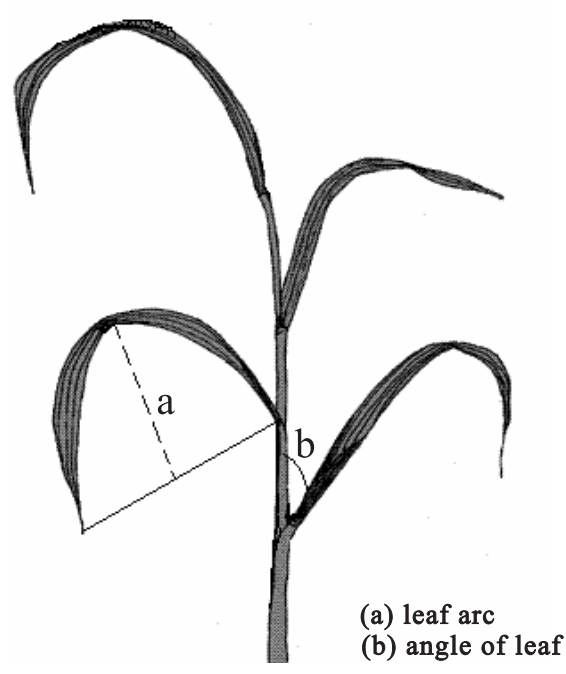

Figure 1. Diagram illustrating the definition of leaf arc (measured by the distance between the midpoint of the line joining the apex to the point of blade insertion - sheath and the midpoint on the adaxial surface of the leaf) and leaf insertion angle of rice plants. 
The dry material was ground in a Wiley-type mill, passed through a sieve of $0.84 \mathrm{~mm}$ and mineralized in a solution $\left(3: 1 \mathrm{v} \mathrm{v}^{-1} \mathrm{HNO}_{3}+\mathrm{HClO}_{4}\right.$ concentrated) where the levels of $\mathrm{Mn}, \mathrm{Fe}$ and $\mathrm{Ca}$ were determined by atomic absorption spectrophotometry. The Si contents were determined by the method of alkaline digestion and dosage by a colorimetric method, modified by Korndorfer et al., (2004).

The Analysis of Variance (ANOVA) was performed and the Si x Mn interaction was evaluated to assess the linear and quadratic effects of doses of $\mathrm{Mn}$ within each level of Si, by testing at the 5 and $1 \%$ levels by the $\mathrm{F}$ test. Regression equations were adjusted for variables evaluated as a function of doses of $\mathrm{Mn}$, with and without the addition of Si to the solutions.

\section{RESULTS AND DISCUSSION}

\section{Response to $\mathrm{Si}$}

The addition of Si to the nutrient solution, regardless of the dose of $\mathrm{Mn}$, significantly increased the dry matter production of roots, sheaths and leaves with the greatest gain in the shoot, which caused a decrease in root/shoot ratio (Tables 1 and 2). Similarly, Deren et al. (1994) and Zanão Júnior et al. (2009b) obtained positive responses in the biomass production of rice with the addition of Si. On the other hand, Liang et al. (1994), Carvalho (2000), Silva \& Bohnen
(2001) and Mauad et al. (2003) found no significant change in dry matter yield of vegetative parts of rice with the application of Si. This lack of response to the application of $\mathrm{Si}$ in the nutrient solution may be related to the low doses of Si used, the low solubility of the sources used or to the polymerization with the formation of colloidal particles of hydrated silica. These occurrences may, according to Birchall (1995), impede the adjustment of doses of monosilicic acid. Yet, in studies conducted in soil, the lack of response may be seen when the initial content of available silicon in the soil is above the critical level, as occurred in the work of Carvalho (2000) and Mauad et al. (2003). According to Korndorfer et al. (1999), Si content available in the soil (extracted with $\mathrm{CaCl}_{2} 0.05 \mathrm{~mol} \mathrm{~L}^{-1}$ ) less than $6-8 \mathrm{mg} \mathrm{dm}^{-3}$, in general, indicates high probability of response to the application of $\mathrm{Si}$.

The addition of Si to the nutrient solution decreased the angle of leaf insertion and the arc of the leaf in rice plants, modifying its architecture and favoring the predominance of more erect leaves on plants supplied with Si (Table 2; Figure 2). The decrease was, on average, $19^{\circ}$ in the angle and $3.45 \mathrm{~cm}$ in the foliar arc of plants supplied with Si compared with those not supplied. Keulen (1986) mentioned the leaf insertion angle as one of the most important features of the plant related to production capacity, emphasizing that the photosynthetic rate in plants with more decumbent leaves (larger angle) is smaller, being indifferent to the increase of the leaf area index (LAI) which is described by Brougham (1956) as the

Table 1. Analysis of variance, with the split of Si $x$ Mn interaction for the evaluation of linear and quadratic effects of doses of $\mathrm{Mn}$, at each level of $\mathrm{Si}\left(\mathrm{d} / \mathrm{Si}=0 \mathrm{mmol} \mathrm{L}^{-1} ; \mathrm{d} / \mathrm{Si}=2 \mathrm{mmol} \mathrm{L}{ }^{-1}\right.$, respectively)

\begin{tabular}{|c|c|c|c|c|c|c|c|}
\hline \multirow{2}{*}{ Variable } & \multirow{2}{*}{$\begin{array}{l}\text { MSSi } \\
\text { (1DF) }\end{array}$} & \multicolumn{2}{|c|}{$\mathrm{d} / \mathrm{Si}=0 \mathrm{mmol} \mathrm{L}-1$} & \multicolumn{2}{|c|}{$\mathrm{d} / \mathrm{Si}=2 \mathrm{mmol} \mathrm{L}-1$} & \multirow{2}{*}{$\begin{array}{l}\text { MSRes } \\
\text { (20 DF) }\end{array}$} & \multirow{2}{*}{ CV } \\
\hline & & $\begin{array}{c}\text { MSMnl } \\
\text { (1DF) }\end{array}$ & $\begin{array}{c}\text { MSMnq } \\
\text { (1DF) }\end{array}$ & $\begin{array}{c}\text { MSMnl } \\
\text { (1DF) }\end{array}$ & $\begin{array}{l}\text { MSMnq } \\
\text { (1DF) }\end{array}$ & & \\
\hline & & & & & & & $\%$ \\
\hline DMR & $0.076^{* *}$ & $0.111^{* *}$ & $0.128 * *$ & 1.90E-05 & 0.004 & 0.004 & 8.40 \\
\hline DML & $2.332^{* *}$ & $0.128^{*}$ & $0.539 * *$ & 0.028 & 0.021 & 0.021 & 20.07 \\
\hline DMS & $1.133^{* *}$ & $0.154^{*}$ & $0.397 * *$ & 0.012 & 0.030 & 0.030 & 13.70 \\
\hline MSPA & $6.717^{* *}$ & $0.564^{* *}$ & $1.860^{* *}$ & 0.003 & 0.059 & 0.059 & 12.62 \\
\hline R/AP & $0.265^{* *}$ & 0.010 & $0.080 * *$ & 0.000 & 0.009 & 0.009 & 21.08 \\
\hline ANG & $2.73 \mathrm{E}+03^{* *}$ & $50.457^{*}$ & 21.943 & 8.314 & 9.863 & 9.863 & 16.47 \\
\hline $\mathrm{ARC}$ & $89.441^{* *}$ & 0.867 & 0.009 & 0.530 & 0.431 & 0.431 & 21.65 \\
\hline CMnR & $2.42 \mathrm{E}+05^{* *}$ & $5.29 \mathrm{E}+05^{* *}$ & 13.25 & $1.26 \mathrm{E}+06^{* *}$ & 497.523 & 497.523 & 6.40 \\
\hline CSiR & $5.427^{* *}$ & $0.067^{*}$ & $1.00 \mathrm{E}-06$ & $0.041^{*}$ & 0.008 & 0.008 & 11.77 \\
\hline $\mathrm{CMnS}$ & $8.37 \mathrm{E}+05^{* *}$ & $2.51 \mathrm{E}+06^{* *}$ & $2.01 \mathrm{E}+04^{*}$ & $1.12 \mathrm{E}+06^{* *}$ & 2453.724 & 2453.724 & 6.67 \\
\hline CSiS & $92.19^{* *}$ & 0.009 & 0.022 & $2.155^{* *}$ & 0.068 & 0.068 & 9.66 \\
\hline $\mathrm{CMnL}$ & $2.75 \mathrm{E}+06^{* *}$ & $7.06 \mathrm{E}+06^{* *}$ & $1.79 \mathrm{E}+05^{* *}$ & $1.93 \mathrm{E}+06^{* *}$ & 4111.824 & 4111.824 & 7.34 \\
\hline CSiL & $277.37^{* *}$ & $0.173^{*}$ & 0.01 & 0.079 & 0.028 & 0.028 & 4.04 \\
\hline
\end{tabular}

DMR, DML, DMS and DMAP: dry matter production of roots, leaves, sheaths and aerial parts, respectively; R/PA: root/aerial parts; Ang: angle of insertion of the leaf; ARC: leaf arc; CMnR: Mn concentration in roots; CSiR: Si concentration in roots; CMnS: Mn concentration in sheaths; CSiS: Si concentration in sheaths; CMnL: Mn concentration in leaves and TSiL: Si concentration in leaves. MSRes: mean square of residue; MSSi: mean square of the effects of Si; MSMnl: mean square of the linear effect of doses of Mn; MSMnq: mean square of the quadratic effect of doses of Mn. * and **: significant at 5 and $1 \%$, respectively, by $\mathrm{F}$ test. DF: degrees of freedom; CV: coefficient of variation. 
Table 2. Production of root dry matter (DMR), sheaths (DMS), leaves (DML), aerial parts (DMAP), root/ aerial parts ratio (R/AP), angle of leaf insertion (ANG) and leaf arc (ARC) of rice plants grown on nutrient solution with three doses of $\mathrm{Mn}$ in the absence or presence of $\mathrm{Si}$

\begin{tabular}{|c|c|c|c|c|c|c|c|c|}
\hline Si & Mn & DMR & DMS & DML & DMAP & R/AP & ANG & ARC \\
\hline $\mathrm{mmol} \mathrm{L}^{-1}$ & $\mu \mathrm{mol} \mathrm{L}-1$ & & & g/plant & & - & 。 & $\mathrm{cm}$ \\
\hline \multirow[t]{4}{*}{0} & 0,5 & 0,55 & 0,40 & 0,50 & 0,89 & 0,64 & 31,60 & 4,96 \\
\hline & 2,5 & 0,81 & 0,84 & 1,00 & 1,84 & 0,45 & 27,00 & 4,90 \\
\hline & 10,0 & 0,82 & 0,76 & 0,86 & 1,62 & 0,52 & 26,40 & 4,42 \\
\hline & Mean & $0,73 \mathrm{~b}$ & $0,607 \mathrm{~b}$ & $0,78 \mathrm{~b}$ & $1,45 \mathrm{~b}$ & $0,54 \mathrm{a}$ & $28,60 \mathrm{a}$ & $4,76 \mathrm{a}$ \\
\hline \multirow[t]{4}{*}{2} & 0,5 & 0,83 & 0,96 & 1,39 & 2,35 & 0,36 & 10,60 & 1,76 \\
\hline & 2,5 & 0,82 & 1,14 & 1,35 & 2,48 & 0,31 & 9,40 & 1,04 \\
\hline & 10,0 & 0,82 & 1,08 & 1,28 & 2,36 & 0,35 & 8,60 & 1,12 \\
\hline & Mean & $0,82 \mathrm{a}$ & $1,06 \mathrm{a}$ & $1,34 \mathrm{a}$ & $2,40 \mathrm{a}$ & $0,34 \mathrm{~b}$ & $9,53 \mathrm{~b}$ & $1,31 \mathrm{~b}$ \\
\hline CV (\%) & & 8,40 & 13,70 & 20,07 & 12,62 & 21,08 & 21,65 & 16,47 \\
\hline
\end{tabular}

Means followed by different letters in columns differ by $5 \%$ by the $\mathrm{F}$ test.

surface area of leaves in comparison to the area of soil under the plant. Similarly, Moreira (2001) mentions that the angle of leaf insertion is directly involved in the processes of interception and absorption of photosynthetically active radiation (PAR). In practice, it is expected that in plants with more decumbent leaves the leaves shadow one another making the plants reach a maximum LAI earlier than the plants with more erect leaves which intercept the photosynthetic radiation more efficiently. In this work, the modification of the plant architecture of rice due to the addition of Si to the solution certainly contributed to greater dry matter production. Additionally, it should be pointed out the presence of stomata on both sides of the leaf blade of rice, which, in plants with more erect leaves, increases the photosynthetic efficiency, decreases sweating, and increases the photosynthetic rate, as observed in rice fertilized with Si (Agarie et al., 1998; Carvalho et al., 2008).

In this work we observed lower rigidity of the leaves and sheaths with plant inclination, mutual shading and lower production in the rice plants grown on solutions without the addition of Si (Figure 2).

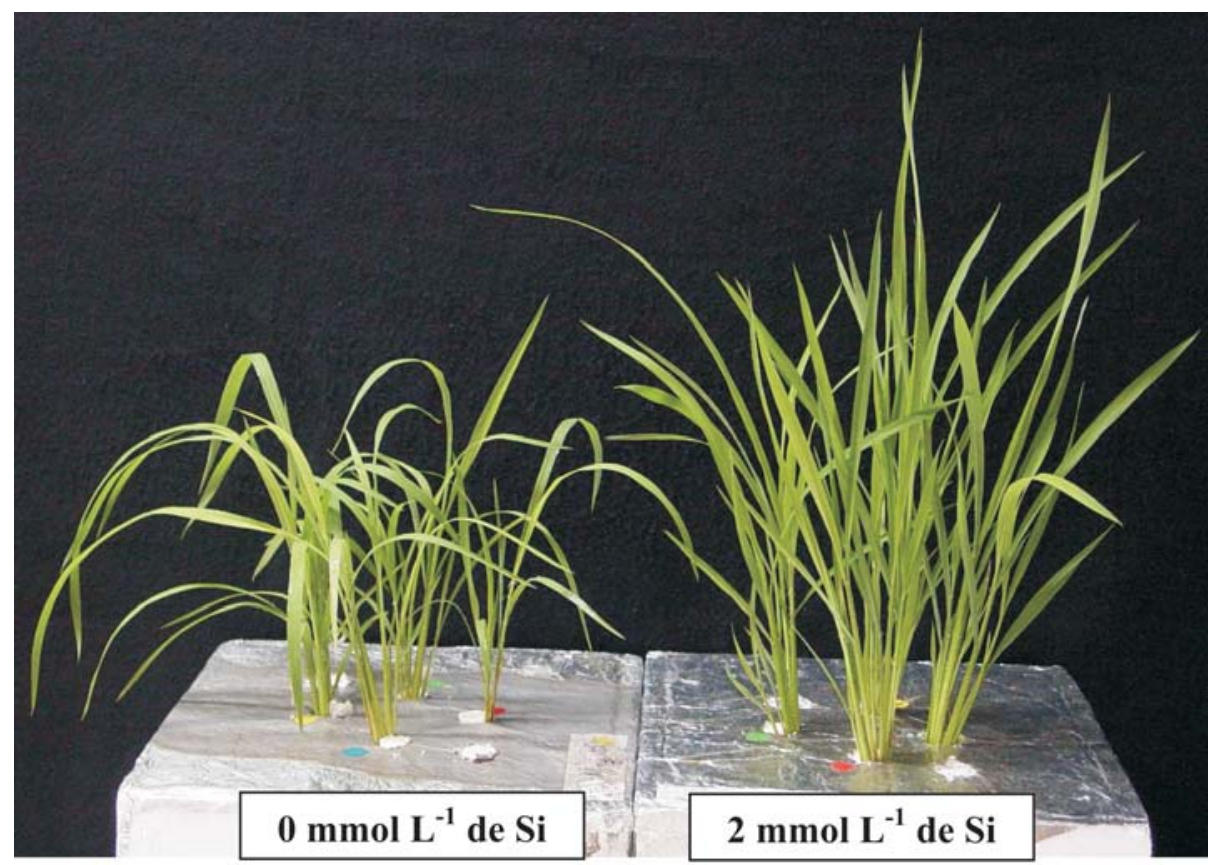

Figure 2. Aspect of the architecture of rice plants (Metica-1) grown in nutrient solution in the presence and absence of Si at the dose of $0.5 \mathrm{mmol} \mathrm{L}^{-1}$ of $\mathrm{Mn}$. 
Dobermann \& Fairhurst (2000) relate these symptoms to a deficiency of Si and mention that no other nutritional disorder in rice causes this type of symptom.

Analyzing the root/shoot ratio (Table 2), the allocation of dry matter to these two parts of the plant may indicate how plant growth occurred in response to treatments. According to Gunatilleke et al. (1997), under non-limiting nutrient regimes in general, the species have a lower root/shoot ratio due to the shoot growth. According to Chapin (1980), usually, a restriction of nutrients in conditions of not limiting light leads to the increased allocation of dry matter to the root in detriment of the shoot. In the present work, the results of the addition of $2 \mathrm{mmol} \mathrm{L}^{-1}$ of Si (Table 2) agree with these comments. In the presence of $\mathrm{Si}$, the allocation of dry matter in shoots was stimulated, possibly by increased photosynthetic activity in non-limiting nutritional conditions. Assis et al. (2000), working with two organic soils and the missing element technique, found that plants receiving full fertilization $+\mathrm{Si}$ had a lower root/shoot ratio than plants grown with complete fertilization $\mathrm{Si}$, in both soils.

There were higher Si contents in leaves and sheaths than in roots (Table 3 ). This is because the $\mathrm{Si}$ is transported from roots to shoots through the xylem and the water loss by transpiration in the leaves leads to the formation of amorphous hydrated silica, mainly in epidermal cells of leaf tissues (Blackman, 1969).

Si concentrations (on average $71.5 \mathrm{~g} \mathrm{~kg}^{-1}$ ) in the leaves of rice grown in treatments with the addition of this factor (Table 3) are adequate, according to Dobermann \& Fairhurst (2000), who assert that the Si contents in leaves must be above $50 \mathrm{~g} \mathrm{~kg}^{-1}$. When compared to macronutrients, the concentration of $\mathrm{Si}$ is larger than that found for any of them (data not presented). In cultivation without addition of $\mathrm{Si}$, the plants showed a foliar average of Si equal to $10.7 \mathrm{~g} \mathrm{~kg}^{-1}$ which was below the concentration considered adequate and occurred due to the presence of $\mathrm{Si}$ as a contaminant in chemical reagents, water and air (Werner \& Roth, 1983). Being below the adequate leaf Si concentration (Table 3), it was not sufficient to provide beneficial effects to plants. The concentration of monosilicic acid was determined in the distilled water used in the experiment, showing the average value of $0.1 \mathrm{mg} \mathrm{L}^{-1}$. Bohnen \& Silva (2001) and Mauad et al. (2003) found, in the nutrient solution, no positive response of rice to $\mathrm{Si}$, and detected low levels of leaf $\mathrm{Si}$ (well below the levels considered appropriate). The former authors found $15 \mathrm{~g} \mathrm{~kg}^{-1} \mathrm{Si}$ in shoots of plants grown on nutrient solutions, values close to those found in plants grown without $\mathrm{Si}$ in the present work.

During the experimental work we observed the presence of white precipitate on the styrofoam plate used to support the plants and cover the pot. To show this occurrence, the styrofoam plates of some experimental units were covered with dark polyethylene for fifteen days. The precipitate formation was the result of fallen drops from the process of guttation and was not observed in plants grown in treatments without $\mathrm{Si}$ application. In the plants grown in the treatments that received $\mathrm{Si}$, the precipitate was formed in abundance on the plate (Figure 3). The polyethylene was removed and washed with $100 \mathrm{~mL}$ of water to determine the content of $\mathrm{Si}$ in the precipitate which was found in a concentration of approximately $50 \mathrm{mg} \mathrm{L}^{-1}$.

The concentrations of $\mathrm{Mn}$ were higher in roots of plants on the solutions that received Si compared to plants on solutions that did not receive it (Table 3). One explanation would be the deposition of $\mathrm{Mn}$ on the root surfaces, a result of the oxidation process, since, according to Horigushi (1988), Si improves the oxidizing power of the roots. It is known that $\mathrm{Si}$ increases the volume and gives rigidity to the aerenchyma which is an air channel present in the

Table 3. Concentrations of silicon and manganese in leaves and roots of rice plants grown in nutrient solution with different doses of Mn with and without the addition of $\mathrm{Si}$

\begin{tabular}{|c|c|c|c|c|c|c|c|}
\hline $\mathrm{Si}$ & Mn & $\mathrm{CMnR}^{(1)}$ & CMnB & CMnF & CSiR & CSiB & CSiF \\
\hline $\mathrm{mmol} \mathrm{L}^{-1}$ & $\mu \mathrm{mol} \mathrm{L}-1$ & 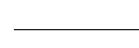 & $\mathrm{mg} \mathrm{kg-1}$ & - & & $\mathrm{g} \mathrm{kg}^{-1}$ & 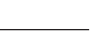 \\
\hline \multirow[t]{4}{*}{0} & 0.5 & 104.60 & 565.40 & 650.00 & 2.72 & 9.64 & 9.96 \\
\hline & 2.5 & 194.00 & 677.60 & 723.00 & 3.02 & 8.84 & 9.88 \\
\hline & 10.0 & 540.00 & 1487.60 & 2158.40 & 4.26 & 9.92 & 12.26 \\
\hline & Mean & $279.53 \mathrm{~b}$ & $910.20 \mathrm{a}$ & $1177.13 \mathrm{a}$ & $3.33 \mathrm{~b}$ & $9.47 \mathrm{~b}$ & $10.70 \mathrm{~b}$ \\
\hline \multirow[t]{4}{*}{2} & 0.5 & 85.20 & 129.60 & 110.60 & 11.84 & 40.00 & 70.08 \\
\hline & 2.5 & 459.20 & 695.60 & 567.80 & 10.72 & 44.06 & 72.14 \\
\hline & 10.0 & 832.60 & 903.20 & 1034.80 & 12.40 & 49.52 & 72.32 \\
\hline & Mean & $459.00 \mathrm{a}$ & $576.13 \mathrm{~b}$ & $571.07 \mathrm{~b}$ & $10.72 \mathrm{a}$ & $44.53 \mathrm{a}$ & $71.51 \mathrm{a}$ \\
\hline CV (\%) & & 6.40 & 6.67 & 7.34 & 11.77 & 9.66 & 4.04 \\
\hline
\end{tabular}

(1) CSiR: Si concentration in roots; CSiS: Si concentration in sheaths; TSiL: Si concentration in leaves; CMnR: Mn concentration in roots; CMnS: Mn concentration in sheaths and CMnL: Mn concentration in leaves. Means followed by different letters in columns differ by $5 \%$ by $\mathrm{F}$ test. 


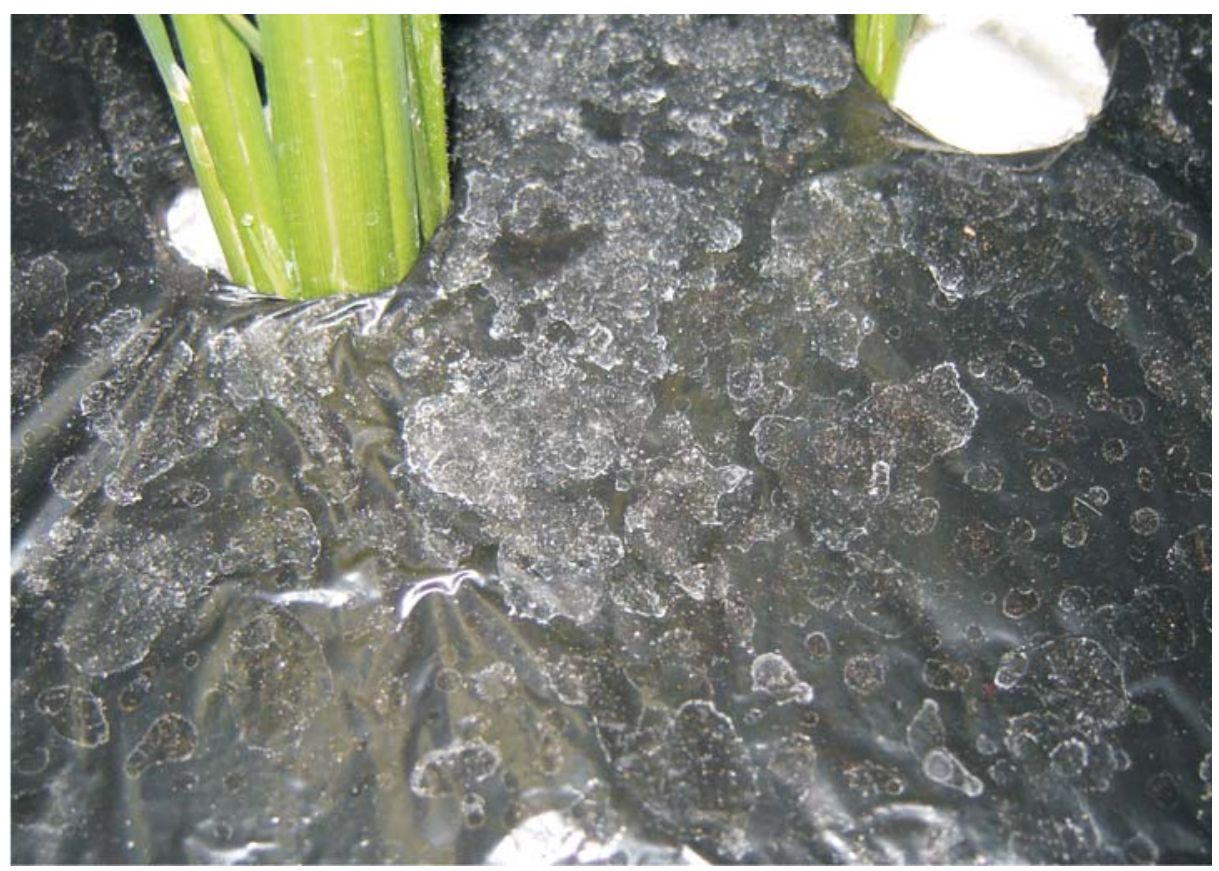

Figure 3. White precipitate on the polyethylene cap that covered the pots with plants.

rice roots, and other plants, involved in the exchange of oxygen and other gases within the plant. Lignin is a component of the cell wall which binds $\mathrm{Si}$ (Inanaga et al., 1995), more in roots than in leaves. Thus, the occurrence of more binding sites for Mn in the cell wall of roots of plants supplied with Si may have been the reason for the higher concentrations of Mn found. Moreover, Sangster (1978) observed that Si was deposited in open spaces in the roots. A precipitation of Si along with Mn, would explain the higher levels of this micronutrient in the roots of plants supplied with $\mathrm{Si}$.

In leaves, the situation changed with plants grown on Si supplied solutions showing lower Mo concentrations than plants grown on solutions without Si (Table 3). This suggests that, compared to what occurs in the roots, in rice leaves the Si supply changes the allocation of $\mathrm{Mn}$ in response to increasing $\mathrm{Mn}$ levels. In plants grown on solution with $\mathrm{Si}$, the concentrations of $\mathrm{Mn}$ in roots, sheats and leaves showed closer values as compared to plants grown without a Si supply (Table 3). This was confirmed by the percentage distribution of Mn between roots sheats and leaves which was more homogenous in plants grown on solutions with Si (Figure 4). In the treatments without the addition of $\mathrm{Si}$, the average content of $\mathrm{Mn}$ increased in roots $\left(279 \mathrm{mg} \mathrm{kg}^{-1}\right)$ in sheaths $\left(910 \mathrm{mg} \mathrm{kg}^{-1}\right)$ and leaves $\left(1,177 \mathrm{mg} \mathrm{kg}^{-1}\right)$ in the proportion 1.0:3.3:4.2 (roots:sheaths:leaves). With the addition of $\mathrm{Si}$, the average content of $\mathrm{Mn}$ in those parts of the plants decreased and the ratio roots:sheaths: leaves changed to $1.0: 1.3: 1.2$ (459 $\mathrm{mg} \mathrm{kg}^{-1}$ in roots; $576 \mathrm{mg} \mathrm{kg}^{-1}$ in sheaths; $571 \mathrm{mg} \mathrm{kg}^{-1}$ in leaves).

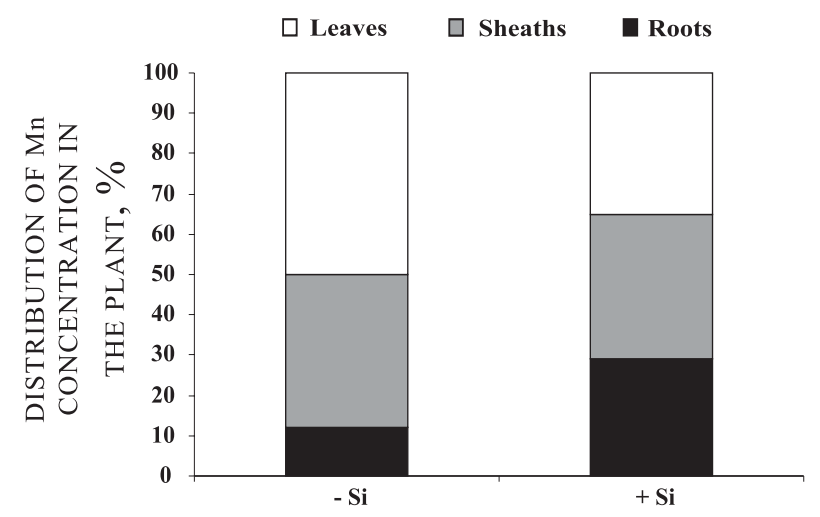

Figure 4. Percentage distribution of $\mathrm{Mn}$ in roots, sheaths and leaves of rice, as related to the total $\mathrm{Mn}$ in the plant, as a function of Si added to the nutrient solution.

\section{Response to Mn}

Without Si, the dry matter production of all plant parts increased significantly with increasing doses of Mn, further diminishing, which indicates the toxic effect of $\mathrm{Mn}$ at the dose of $10 \mathrm{mmol} \mathrm{L}^{-1}$. The linear (1) and quadratic (q) functions indicate that the quadratic model fits the best to express the response in dry matter production as a function of increasing doses of $\mathrm{Mn}$. With the addition of Si, the dry matter yield remained uniform even with increasing doses of $\mathrm{Mn}$, with no significant effect of the micronutrient on the dry matter yield (Tables 1 and 3). The visual symptoms of Mn deficiency were not detected, even in plants grown at the lowest dose $\left(0.5 \mathrm{mmol} \mathrm{L}^{-1} \mathrm{Mn}\right)$. 
A deficiency of Mn has a negative impact on productivity because it interferes in photosynthesis. This micronutrient participates in many biochemical reactions in plant photosynthesis, acting in the photolysis of water, oxygen evolution and chlorophyll synthesis (Thompson \& Huber, 2007). In the present work, the effect of the Mn doses was shown by the increased dry matter production of the rice plants in response to the increasing $\mathrm{Mn}$ concentration in the solution (Tables 1 and 3). With the addition of Si to the solution, there was no effect of Mn doses. The highest average values of dry matter production of roots, sheaths and leaves found in the treatments with $\mathrm{Si}$ addition, as compared to treatments without $\mathrm{Si}$ (Tables 1 and 2), suggests that the addition of this element resulted in a greater efficiency for plant growth, regardless of the Mn concentrations in the solution.

In the absence of $\mathrm{Si}$, with the increase of $\mathrm{Mn}$ in the nutrient solution, there was a decrease of the leaf insertion angle with a negative linear response (Tables 1 and 2). This may have been the result of an increased production of lignin, due to $\mathrm{Mn}$ which provides additional rigidity to the cell wall and therefore to the leaves. With the addition of Si to the solution, the leaf insertion angle decreased, and even with increasing doses of $\mathrm{Mn}$ it was constant $\left(\mathrm{y}^{-}=\mathrm{w}=\right.$ 9.53) (Table 2). As already discussed, regarding $\mathrm{Si}$, the angle of leaf insertion is directly involved in the processes of interception and absorption of photosynthetically active radiation. Similarly, the gain in dry matter production due to the increase of $\mathrm{Mn}$ in the nutrient solution may be related to decreased leaf insertion angle in rice plants in response to increasing Mn levels (Table 2). The effect of Mn on the decrease of the leaf insertion angle in rice was not expressed in the treatments where Si was added, probably due to the direct action of Si decreasing this angle.

In response to doses of Mn, the Si concentrations in roots were adjusted using the linear model, with or without the addition of Si to the solution whereas in the sheaths and leaves, the Si concentrations were adjusted using the quadratic model, for the solution without Si (Tables 1 and 3).

Fageria et al. (1984) reported that the level of Mn considered toxic to plants is above $1,000 \mathrm{mg} \mathrm{kg}^{-1}$ (with appropriate values between 30 and $600 \mathrm{mg} \mathrm{kg}^{-1}$ ). Tanaka \& Yoshida (1970) mentioned that the Mn concentrations can reach values exceeding $3,000 \mathrm{mg} \mathrm{kg}^{-1}$ without causing toxic symptoms. ElJaoual \& Cox (1998) point out that these levels are dependent on other factors such as genotype, species and environmental conditions. In this study, the concentration of $\mathrm{Mn}$ in leaves in rice plants grown on solutions with $0.5 \mathrm{~mol} \mathrm{~L}^{-1} \mathrm{Mn}$ without Si was $650 \mathrm{mg} \mathrm{kg}^{-1}$, whereas with the addition of Si this value dropped to $110 \mathrm{mg} \mathrm{kg}^{-1}$. In the solution with $10 \mathrm{mmol} \mathrm{L}^{-1} \mathrm{Mn}$ (higher rate), without the addition of $\mathrm{Si}, \mathrm{Mn}$ concentration in leaves was $2,158 \mathrm{mg} \mathrm{kg}^{-1}$ (well above the range considered toxic), falling to $1,035 \mathrm{mg} \mathrm{kg}^{-1} \mathrm{Mn}$ (above the level considered appropriate, however, below the limit considered toxic) with the addition of Si. In the corresponding results, the average concentrations of $\mathrm{Mn}$ in leaves $\left(1,177 \mathrm{mg} \mathrm{kg}^{-1}\right)$ and sheaths $\left(910 \mathrm{mg} \mathrm{kg}^{-1}\right)$ in the treatments without Si dropped to $571 \mathrm{mg} \mathrm{kg}^{-1}$ (leaves) and $576 \mathrm{mg} \mathrm{kg}^{-1}$ (sheath) with the addition of Si to the solution (Table 3).

The action of Si alleviating Mn toxicity in plants, as occurred in the present work, is reported in many studies (Horst \& Marschner, 1978; Iwasaki et al., 2002; Shi et al., 2005 and Liang et al., 2007). According to El-Jaoual \& Cox (1998), to increase the tolerance of a plant to $\mathrm{Mn}$ toxicity, the involved mechanism must avoid the absorption and translocation of this element to the shoot or improve its distribution in the plant. In the present work there was a simultaneous diminishing of the $\mathrm{Mn}$ concentration in shoots with its increase in roots (Figure 4). Thus we see that the addition of Si helped block the transport of $\mathrm{Mn}$ from roots to the shoots, providing a more homogeneous distribution of Mn among the plant parts. Working with beans, Horst \& Marschner (1978) showed that Si reduced transport of $\mathrm{Mn}$ from roots to shoots, homogenizing its distribution, and avoiding the concentration of this element in spots on the leaves as well as the formation of necrotic spots. Iwasaki et al. (2002) found that $\mathrm{Si}$ reduces the concentration of $\mathrm{Mn}$ by increasing its adsorption by the cell wall and also by the action of the soluble $\mathrm{Si}$, which reduces the concentration of $\mathrm{Mn}$ in the environment. In cucumber plants grown with Si supply, Rogalla \& Römheld (2002) found less than $10 \%$ of Mn in the symplast and more than $90 \%$ bound to the cell wall. Regarding plants that did not receive $\mathrm{Si}$, the distribution of Mn was similar in the two compartments. These authors claim that tolerance of cucumber plants to Mn toxicity is also due to its attachment to the cell wall, which lowers its concentration in the symplast. More recently it was found that Si reduces membrane lipid peroxidation caused by excess Mn, causing a significant increase in the amount of antioxidants of enzymatic nature (superoxide dismutase, dihidroascorbato reductase, glutathione reductase and ascorbate peroxidase) and nonenzymatic (ascorbate and glutathione) (Shi et al., 2005). Another hypothesis that should be studied is a possible formation of compounds of Si and $\mathrm{Mn}$ in the nutrient solution and its effects of Mn uptake by plants.

Mn concentration in roots, sheaths and leaves increased linearly, for both doses of $\mathrm{Si}$, in response to the increase of $\mathrm{Mn}$ concentration in the solution (Tables 1 and 3), thus confirming increased absorption of $\mathrm{Mn}$ when the concentration of the element in nutrient solution is higher. Adding Mn to soil, Pereira et al. (2001) found that its levels in leaves of rice cultivars increased quadratically in response to higher 
rates. Similar results were found for guava (Salvador et al., 2003) and soybean (Oliveira Júnior et al., 2000).

The addition of Si to the solution increased the content of Mn in roots and decreased in leaves and sheaths (Table 3) showing a lower translocation of Mn to leaves which indicates that Si reduces the toxicity caused by Mn, what may be an alternative to alleviate such adversity. In areas where excess $\mathrm{Mn}$ is a problem, studies to establish rates and sources in order to increase the Si availability to rice plants must be implemented to supplement information for fertilizer recommendations for this crop.

Studies under field conditions should be performed in order to find the best ways, times, sources and doses to be recommended for silicon fertilization for rice. The use of Si in regular fertilization of rice, especially in soils deficient in this element, must be considered both to increase productivity and to restore the extracted Si by the plants. In soils where the levels of Mn are considered high, this practice may fend off the harmful effects of Mn.

\section{CONCLUSIONS}

1. Both the supply of Si and Mn (only in the absence of Si) to the plants decrease the leaf insertion angle of the rice plant improving its architecture and promoting dry matter production.

2. Si provides a more homogeneous distribution of Mn among roots, sheaths and leaves in the rice plant.

3. There is interaction between Si and Mn during the growth of rice, with Si benefiting the plant and minimizing the adverse effects of toxicity caused by Mn in plants.

\section{ACKNOWLEDGEMENTS}

The authors Fontes and Korndörfer thank the National Council of Scientific and Technological Development $(\mathrm{CNPq})$ for the research fellowship. Zanão Júnior was supported by the Fundação de Amparo à Pesquisa do Estado de Minas Gerais (FAPEMIG) and CNPq. The authors would also like to express their appreciation to Prof. Fabrício de Ávila Rodrigues for technical assistance.

\section{LITERATURE CITED}

AGARIE, S.; HANAOKA, N.; UENO, O.; MIYAZAKI, A.; KUBOTA, F.; AGATA, W. \& KAUFMAN, P.B. Effects of silicon on tolerance to water defict and heat stress in rice plants (Oryza sativa L.), monitored by electrolyte leakage. Plant Produc. Sci., 1:96-103, 1998.
ALVAREZ, J. \& DATNOFF, L.E. The economic potential of silicon for integrated management and sustainable rice production. Crop. Protec., 20:43-48, 2001.

ASSIS, M.P.; CARVALHO, J.G.; CURI, N.; BERTONI, J.C. \& ANDRADE, W.E.B. Limitações nutricionais para a cultura do arroz em solos orgânicos sob inundação. I. Crescimento. Ci. Agrotec., 24:87-95, 2000.

BASILE-DOELSCH, I.; MEUNIER, J.D. \& PARRONM, C. Another continental pool in the terrestrial silicon cycle. Nature, 433:399-402, 2005.

BIRCHALL, J.D. The essentiality of silicon in biology. Chem. Soc. Rev., 24:351-357, 1995.

BLACKMAN, E. Observations on the development of the silica cells of the leaf sheath of wheat (Triticum aestivum). Can. J. Bot., 47:827-838, 1969.

BROUGHAM, R.M. Effects of intensity of defoliation on regrowth of pastures. Austr. J. Agric. Res., 7:377-387, 1956.

CARVALHO, J.C. Análise de crescimento e produção de grãos da cultura do arroz irrigado por aspersão em função da aplicação de escórias de siderurgia como fonte de silício. Botucatu, Universidade Estadual Paulista, 2000. 119p. (Tese de Mestrado)

CARVALHO, M.P.; ZANÃO JÚNIOR, L.A.; ÁVILA, V.T. \& ALVAREZ V., V.H. Características fisiológicas de plantas de arroz cultivadas em solução nutritiva com fontes de silício. In: CONGRESSO BRASILEIRO DE BOTÂNICA, 59., Natal, 2008. Anais. Natal, Sociedade Brasileira de Botânica, 2008. CD-ROM.

CHAPIN, F.S. The mineral nutrition of wild plants. Ann. Rev. Ecol. Syst., 11:261-285, 1980.

CLARKSON, D.T. The uptake and translocation of manganese by plant roots. In: GRAHAM, R.D.; HANNAM, R.J. \& UREN, N.C., eds. Manganese in soils and plants. Dordrecht, Kluwer Academic, 1988. p.101-111.

DEREN, C.W.; DATNOFF, L.E.; SNYDER, G.H. \& MARTIN, F.G. Silicon concentration, disease response, and yield components of rice genotypes grown on flooded organic histosols. Crop Sci., 34:733-737, 1994.

DOBERMANN, A. \& FAIRHURST, T. Rice nutrient disorders \& nutrient management. Los Baños, Potash \& Phosphate Institute (PPI), Potash \& Phosphate Institute of Canada (PPIC) and International Rice Research Institute, 2000. 191p. (Handbook Series)

EDWARDS, D.G. \& ASHER, C.J. Tolerance of crop and pasture species to manganese toxicity. In: SCAIFE, ed. PLANT NUTRITION COLLOQUIUM, 8., Warwick, 1982. Proceedings... Farnham Royal, Commonwealth Agricultural Bureau, 1982. p.140-150.

EL-JAOUAL, T. \& COX, D.A. Manganese toxicity in plants. J. Plant Nutr., 21:353-386, 1998.

FAGERIA, N.K. Adubação e nutrição mineral da cultura de arroz. Rio de Janeiro, Embrapa, 1984. 341p. 
FAGERIA, N.K.; BAETA, A.B.E.; BARBOSA FILHO, M.P. \& GUIMARÃES, C.M. Iron toxicity in lowland rice. J. Plant Nutr., 31:1676-1697, 2008.

FAIRHURST, T.H. \& DOBERMANN, A. Rice in the global food supply. Better Crops Int., 16:3-6, 2002.

GUNATILLEKE, C.V.S.; GUNATILLEKE, I.A.U.N.; PERERA, G.A.D.; BURSLEN, D.F.R.P.; ASHTON, P.M.S. \& ASHTON, P.S. Responses to nutrient addition among seedlings of eight closely related species of Shorea in Sri Lanka. J. Ecol., 85:301-311, 1997.

HORIGUCHI, T. Mechanism of manganese toxicity and tolerance of plants. IV. Effects of silicon on alleviation of manganese toxicity of rice plants. Soil Sci. Plant Nutr., 34:65-73, 1988.

HORST, W.J. \& MARSCHNER, H. Effect of silicon on manganese tolerance of bean plants (Phaseolus vulgaris L.). Plant Soil, 50:287-303, 1978.

INANAGA, S.; OKASAKA, A. \& TANAKA, S. Does silicon exist in association with organic compounds in rice plant? Japan. J. Soil Sci. Plant Nutr., 41:111-117, 1995.

INSTITUTO RIOGRANDENSE DO ARROZ - IRGA. O programa da produtividade, 2004.. Online. Disponível em: http://www.irga.rs.gov.br/arrozrs.htm. Acesso em $20 \mathrm{de}$ ago. de 2005

IWASAKI, K.; MAIER, P.; FECHT, M. \& HORST, W.J. Influence of the apoplastic silicon concentration on the manganese tolerance of cowpea (Vigna unguiculata (L.) Walp.). J. Plant. Physiol., 159:167-173, 2002.

KABATA-PENDIAS, A. \& PENDIAS, H. Trace elements in soils and plants. Boca Raton, CRC Press, 1985. 315p.

KORNDÖRFER, G.H.; ARANTES, V.A.; CORRÊA, G.F. \& SNYDER, G.H. Efeito do silicato de cálcio no teor de silício e na produção de grãos de arroz de sequeiro. R. Bras. Ci. Solo, 23:635-641, 1999.

KORNDÖRFER, G.H.; PEREIRA, H.S. \& NOLA, A. Análise de silício: Solo, planta e fertilizante. Uberlândia, GPSiICIAG-UFU, 2004. 34p. (Boletim Técnico, 2)

KEULEN, H. Plant data. In: van KEULEN, H. \& WOLF, J., eds. Modelling of agricultural production: Weather, soils and crops. Wageningen, Centre for Agricultural Publications and Documentation, 1986. p.246.

LIANG, Y.; SUN, W.; ZHUB, Y.G. \& CHRISTIE, P. Mechanisms of silicon-mediated alleviation of abiotic stresses in higher plants: A review. Environ. Poll., 47:422-428, 2007.

LIANG, Y.C.; MA, T.S.; LI, F.J. \& FENG, Y.J. Silicon availability and response of rice and wheat to silicon in calcareous soils. Comm. Soil Sci. Plant Anal., 25:2285-97, 1994.

LIDON, F.C. \& TEIXEIRA, M.G. Rice tolerance to excess Mn: Implications in the chloroplast lamellae and synthesis of a novel Mn protein. Plant Physiol. Biochem., 38:969-978, 2000 .

MA, J.F. Role of silicon in enhancing the resistance of plants to biotic and abiotic stresses. Soil Sci. Plant Nutr., 50:11 18, 2004.
MA, J.F.; GOTO, S.; TAMAI, K. \& ICHII, M. Role of root hairs and lateral roots in silicon uptake by rice. Plant Physiol., 127:1773-1780, 2001.

MALAVOLTA, E.; VITTI, G.C. \& OLIVEIRA, S.A. Avaliação do estado nutricional de plantas: Princípios e aplicações. Piracicaba, POTAFOS, 1997. 308p.

MATICHENKOV, V.V.; BOCHARNIKOVA, E.A. \& AMMOSOVA, J.A.M. The influence of silicon fertilizers on the plants and soils. Agrochemistry, 12:30-37, 2001.

MAUAD, M.; GRASSI FILHO, H.; CRUSCIOL, C.A.C. \& CORRÊA, J.C. Teores de silício no solo e na planta de arroz de terras altas com diferentes doses de adubação silicatada e nitrogenada. R. Bras. Ci. Solo, 27: 867-873, 2003.

MOREIRA, M.A. Fundamentos do sensoriamento remoto e metodologias de aplicação. São José dos Campos, Instituto Nacional de Pesquisas Espaciais, 2001. 250p.

OLIVEIRA JUNIOR, J.A.; MALAVOLTA, E. \& CABRAL, C.P. Efeitos do manganês sobre a soja cultivada em solo de cerrado do Triângulo Mineiro. Pesq. Agropec. Bras., 35:1629-1636, 2000.

PEREIRA, G.D.; BERTONI, J.C.; CARVALHO, J.G. \& MORAIS, A.R. Doses e modos de adubação com manganês e seus efeitos na produção da cultura do arroz. R. Bras. Ci. Solo, 25:625-633, 2001.

PONNAMPERUMA, F.N. The chemistry of submerged soils Adv. Agron., 24:29-96, 1972.

ROGALLA, H. \& RÖMHELD, V. Role of leaf apoplast in siliconmediated manganese tolerance of Cucumis sativus $\mathrm{L}$. Plant Cell Environ., 25:549-555, 2002.

SALVADOR, J.O.; MOREIRA, A.; MALAVOLTA, E. \& CABRAL, C.P. Influência do boro e do manganês no crescimento e na composição mineral de mudas de goiabeira. Ci. Agrotec., 27:325-331, 2003.

SANGSTER, A.G. Silicon in the roots of higher plants. Am. J. Bot., 65:929-935, 1978

SAVANT, N.K.; SNYDER, G.H. \& DATNOFF, L.E. Silicon management and sustainable rice production. Adv. Agron., 58:151-199, 1997.

SHI, Q.; BAO, Z.; ZU, Z.; HE, Y.; QIAN, Q. \& YU, J. Siliconmediated alleviation of $\mathrm{Mn}$ toxicity in Cucumis sativus in relation to activities of superoxide dismutase and ascorbate peroxidase. Phytochemistry, 66:1551-1559, 2005 .

SILVA, L.S.; \& BOHNEN, H. Rendimento e acúmulo de nutrientes pelo arroz (Oryza sativa) em solução nutritiva com e sem a adição de silício. R. Bras. Ci. Solo, 25:771777,2001

SPOSITO, G. The chemical forms of trace elements in soils. In: THORNTON, I., ed. Applied environmental geochemistry. London, Academic Press, 1982. p.123-167.

TANAKA, A. \& YOSHIDA, S. Nutritional disorders of the rice plant in Asia. Los Baños, International Rice Research Institute, 1970. 51p. (Technical Bulletin, 10). 
THOMPSON, I.A. \& HUBER, D.M. Manganese and plant disease. In: DATNOFF, L.E.; ELMER, W.H. \& HUBER, D.M., eds. Mineral nutrition and plant disease. St Paul, APS Press, 2007. p.139-153.

WERNER, D. \& ROTH, R. Silica metabolism. In: LÄUCHLI, A. \& BIELESKI, R.L., eds. Encyclopedia of plant physiology; New series. Berlin, Springer-Verlag, 1983. v.15b. p.682694.

YOSHIDA, S. Fundamentals of rice crop science. Los Baños, International Rice Research Institute, 1981. 269p.
ZANÃO JÚNIOR, L.A.; RODRIGUES, F.A.; FONTES, R.L.F.; NEVES, J.C.L. \& KORNDORFER, G.H. Rice resistance to brown spot mediated by silicon and its interaction whit manganese. J. Phytopathol., 157:73-78, 2009a.

ZANÃO JÚNIOR, L.A.; FONTES, R.L.F. \& ÁVILA, V.T. Aplicação do silício para aumentar a resistência do arroz à mancha-parda. Pesq. Agropec. Bras., 44:203-206, 2009 b. 